\title{
Effect of Price, Promotion, and Product Quality on Telkomsel Customer Loyalty to Management Study Program Students at Universitas Prima Indonesia
}

\author{
Rosinta Romauli Situmeang ${ }^{1}$, Eci Maria Romanasari Situmorang², \\ Ivan Setiawan ${ }^{3}$, Putri Ananda Br Haloho ${ }^{4}$, Esti Agustina Br Sinulingga ${ }^{5}$, \\ Gratia Angelia Sinuraya ${ }^{6}$ \\ 1,2,3,4,5,6 Universitas Prima Indonesia, Indonesia \\ Corresponding Author: Rosinta Romauli Situmeang
}

\begin{abstract}
This study aims to determine and analyze the effect of price, promotion, and product quality on Telkomsel customer loyalty to Management Study Program Students at Universitas Prima Indonesia. This research is descriptive quantitative. The population of this study was 582 Students of odd semester Management Study Program at Universitas Prima Indonesia and a sample of 100 respondents using the purposive sampling method who had met the requirements. This study uses multiple regression analysis. The results of this study indicate that price, Promotion, and product quality have a positive effect on Telkomsel customer loyalty to Management Study Program Students at Universitas Prima Indonesia.
\end{abstract}

Keywords: Price, Promotion, Product Quality, Customer Loyalty

\section{INTRODUCTION}

Along with the development of communication technology, now we can send messages or talk to someone only through cell phones. The increasing use of cellular phones or smartphones from all walks of life has made telecommunications operator companies compete with each other to win over consumers or customers. In order to achieve its goals, every company strives to deliver or offer its products with the best quality. Not only that, companies also compete to provide attractive price reductions and incentives to consumers. This is done so that companies can maintain customer loyalty or always use their products forever.

Telkomsel is a cellular telecommunications operator in Indonesia which has been operating since 1995 until now. Since its inception, product sales have grown every year. This is because, there are still few companies engaged in telecommunications so that it makes it easier for Telkomsel to sell their products to the market or consumers.

From the data, it can be seen that Telkomsel's revenue and net profit from 2012 to 2018 experienced a significant increase. Compared to other telecommunication companies, namely XL and Indosat, Telkomsel has higher revenue and net profit than other companies. This proves that the quality of Telkomsel's products has good quality so that Telkomsel's customer loyalty is increasing.

From the data above, Telkomsel is still number 1 in the largest number of customers in 2016. This proves that Telkomsel's customer loyalty is greater than other operators.

In the previous year, Telkomsel customers experienced a decrease in customer loyalty. Due to the high level of customer satisfaction with the product or service and their willingness to recommend 
it to others, customers are loyal to their product or service. This kind of consumer loyalty is called customer loyalty. This decline in customer loyalty occurred in the second quarter of 2020, Telkomsel, which has 160.07 million subscribers, then decreased by $1.50 \%$ or equivalent to 2.49 million customers compared to the first quarter of 2020. Then in the fourth quarter of 2020 Telkomsel also experienced a decrease of around 500,000 subscribers. This shows that there has been a decrease in customer loyalty, due to several factors.

Price is believed to be the main element that influences Telkomsel's customer loyalty. In order to achieve the company's goals, it is necessary to maintain appropriate product prices. The products offered by Telkomsel have a high price when compared to products from other telecommunications companies. For example, Indosat internet package products are priced lower than Telkomsel. This can influence customers to switch to other operators because the prices offered are cheaper. Therefore, the company must be wise in determining the price offered.

Another factor that affects customer loyalty is promotion. Promotion is an effort to inform or offer existing products or services and also to remind the company of existing products. With promotions, loyal customers will remember and reuse special products that they used or consumed yesterday. The strategy carried out by Telkomsel in promoting its products is by advertising through TV broadcasts, advertisements on YouTube, radio and banners/pamphlets. Which informs about ongoing promos on Telkomsel. However, many Telkomsel customers switch to other operators because the promos that are informed are not attractive compared to other operators. Telkomsel must design new promos or improve current promos so that customers remain satisfied and prevent them from switching to other operators.

Product quality is one of the main factors. If a product or service performs better, it is said to be of high quality. Good quality products and services are valued by customers, so it is very important to improve the quality of certain offerings. A product even though it has an affordable price but if it does not have good quality then the product will disappoint customers. Performance such as limited network available in various areas or poor internet signal create an unfavorable impression in the minds of customers so that it can affect customer loyalty. Telkomsel has built 233,000 base transceiver stations to reach 95 percent of the population with 4G (BTS) services. With the construction of this BTS, customers can use or access the internet wherever they are, so this is an advantage for Telkomsel in satisfying customers and also maintaining customer loyalty. However, lately the Telkomsel network has often experienced disturbances and repairs. This can disrupt the activities of Telkomsel subscribers in using the internet and also make Telkomsel subscribers switch to other operators because they have a better signal.

This study aims to determine and analyze the effect of price, promotion, and product quality on Telkomsel customer loyalty to Management Study Program Students at Universitas Prima Indonesia.

\section{LITERATURE REVIEW Price}

Kotler and Armstrong (2010:314), "The price of a product or service is the amount of money paid for it, or the amount of value transferred by the client for the benefits of having or using the product or service."

According to Kotler and Armstrong (2008:278), there are 4 indicators that characterize prices, namely:

1. Price accessibility,

2. Product quality and price compatibility,

3. Competitiveness in terms of price,

4. Match between costs and benefits.

\section{Promotion}

Tjiptono (2015:387), promotion is an important component of the marketing mix because it tries to educate, persuade, 
and remind consumers about the company's brands and products.

According to Tjiptono (2008) promotion indicators are:

1. Advertising,

2. Personal selling,

3. Promotion of products and services,

4. Relations with the public.

\section{Product Quality}

Kotler and Keller (2012), "Customers are looking for products that may exceed their expectations in terms of yield or quality."

According to Tjiptono (2010:25), product quality indicators include:

1. Performance,

2. Additional perks,

3. Reliability,

4. With regard to specifications,

5. Durability,

6. Aesthetics

\section{Customer Loyalty}

Olson in Musanto (2004:128), "Customer loyalty is behavioral impulses related to continuous purchases so as to increase customer loyalty for products or services obtained by business entities which can take a long time through various continuous purchasing processes."

According to Griffin (2015:31), a consumer who is devoted to a particular product or service is someone who:

1. Repeat purchases should be made frequently,

2. Choose from a variety of product lines,

3. Referring to others,

4. Demonstrate loyalty/immunity to the pull of rivals.

\section{RESEARCH METHODS}

This research is descriptive quantitative. Descriptive research is a type of research that aims to make a systematic, factual and accurate description of the facts and characteristics of the population of a particular area (Pandiangan et al., 2021). Quantitative research is a systematic scientific study of the parts and phenomena and the causality of their relationships (Pandiangan, 2015).

The population of this study was 582 Students of odd semester Management Study Program at Universitas Prima Indonesia and a sample of 100 respondents using the purposive sampling method who had met the requirements. According Pandiangan et al. (2018) in Sugiyono, purposive sampling is the selection of samples based on certain characteristics that are considered to have relevance to the characteristics of the population that have been known previously.

Data collection techniques with study documentation. Study documentation of reference sources is a form of research that uses library facilities by examining theoretical discussions from various books, articles, and scientific works related to writing (Pandiangan, 2018).

This study uses multiple regression analysis. Based on Tobing et al. (2018), multiple linear regression analysis was used to anticipate the status (up and down) of two or more independent variables (decreased value).

\section{RESULT}

\section{Descriptive Statistics}

Based on the data, it was found that the price variable had a sample of 100 respondents with an average value of 25.30 , the lowest value of 9 , the highest value of 40 and a standard deviation of 5.568 . Promotion has an average value of 25.34, the lowest value of 16 , the highest value of 40 and a standard deviation of 5.111. Product quality has an average value of 40.64 , the lowest value of 24 , the highest value of 60 and a standard deviation of 8.476. Customer loyalty has an average value of 26.06 , the lowest value of 16 , the highest value of 40 and the standard deviation of 5.623 .

\section{Multiple Regression Analysis}

Several linear regression tests were conducted to see how the independent 
variable (independent) affects the dependent variable (dependent).

Table 1: Results of Multiple Regression Analysis Coefficients $^{a}$

\begin{tabular}{|l|l|l|l|l|l|l|}
\hline \multicolumn{2}{|l|}{ Model } & \multicolumn{2}{|l|}{$\begin{array}{l}\text { Unstandardized } \\
\text { Coefficients }\end{array}$} & $\begin{array}{l}\text { Standardized } \\
\text { Coefficients }\end{array}$ & t & Sig. \\
\cline { 3 - 5 } \multicolumn{2}{|l|}{} & B & Std. Error & Beta & & \\
\hline 1 & (Constant) &,- 117 & 1,234 & &,- 095 &, 925 \\
& Price &, 181 &, 071 &, 179 & 2,560 &, 012 \\
& Promotion &, 151 &, 068 &, 137 & 2,237 &, 028 \\
& Product Quality &, 437 &, 050 &, 659 & 8,788 &, 000 \\
\hline
\end{tabular}

The results of this study indicate that price, Promotion, and product quality have a positive effect on Telkomsel customer loyalty to Management Study Program Students at Universitas Prima Indonesia.

\section{CONCLUSION AND SUGGESTION}

The results of this study indicate that price, Promotion, and product quality have a positive effect on Telkomsel customer loyalty to Management Study Program Students at Universitas Prima Indonesia.

Suggestions for this research are:

1. For Researchers, the results of this research can be used as a source of knowledge to expand research knowledge in the field of marketing management.

2. For Further Researchers, it is hoped that they will research or obtain other factors that have an impact on purchasing decisions in order to obtain accurate results and be able to develop research.

3. For companies engaged in telecommunications in Indonesia, companies are required to show price adjustments, product quality, and also carry out good promotions so that many students are more interested in the products offered. According to industry estimates, companies expect the need to create more creative advertisements and promotion strategy to improve the product.

4. Especially at Universitas Prima Indonesia, the knowledge and education of students in the economics faculty are expected to advance as a result of the results of this research.

\section{Acknowledgement: None}

\section{Conflict of Interest: None}

\section{Source of Funding: None}

\section{REFERENCES}

1. Griffin, Jill. (2015). Customer Loyalty, Menumbuhkan dan Mempertahankan Kesetiaan Pelanggan. Jakarta: Erlangga.

2. Kotler, Philip, \& Armstrong, Garry. (2008). Prinsip-prinsip Pemasaran. Edisi 1. Jakarta: Erlangga.

3. Kotler, Philip, \& Armstrong, Garry. (2010). Prinsip-prinsip Pemasaran. Edisi 2. Jakarta: Erlangga.

4. Kotler, Phillip, \& Keller, Kevin Lane. (2012). Manajemen Pemasaran. Jakarta: Erlangga.

5. Musanto, T. (2004). Faktor-faktor Kepuasan Pelanggan dan Loyalitas Pelanggan: Studi Kasus pada CV. Sarana Media Advertising Surabaya. Jurnal Manajemen \& Kewirausahaan, 6(2), 123-136.

6. Pandiangan, Saut Maruli Tua. (2015). Analisis Lama Mencari Kerja Bagi Tenaga Kerja Terdidik di Kota Medan. Skripsi. Medan: Fakultas Ekonomi dan Bisnis, Program Studi Ekonomi Pembangunan, Universitas Sumatera Utara. https://www.academia.edu/52494724/Analis is_Lama_Mencari_Kerja_Bagi_Tenaga_Ker ja_Terdidik_di_Kota_Medan.

7. Pandiangan, Saut Maruli Tua. (2018). Analisis Faktor-faktor yang Mempengaruhi Penawaran Tenaga Kerja Lanjut Usia di Kota Medan. Tesis. Medan: Fakultas Ekonomi dan Bisnis, Program Studi Ilmu Ekonomi, Universitas Sumatera Utara. http://repositori.usu.ac.id/bitstream/handle/1 23456789/10033/167018013.pdf?sequence $=$ 1\&isAllowed $=\mathrm{y}$.

8. Pandiangan, Saut Maruli Tua, Rujiman, Rahmanta, Tanjung, Indra I., Darus, Muhammad Dhio, \& Ismawan, Agus. (2018). An Analysis on the Factors which Influence Offering the Elderly as Workers in Medan. IOSR Journal of Humanities and Social Science (IOSR-JHSS), 23(10), 76-79. DOI: 10.9790/0837-2310087679. 
Eci Maria Romanasari Situmorang et.al. Effect of price, promotion, and product quality on Telkomsel customer loyalty to Management Study Program Students at Universitas Prima Indonesia

9. Pandiangan, Saut Maruli Tua, Resmawa, Ira Ningrum, Simanjuntak, Owen De Pinto, Sitompul, Pretty Naomi, \& Jefri, Riny. (2021). Effect of E-Satisfaction on Repurchase Intention in Shopee User Students. Budapest International Research and Critics Institute-Journal, 4(4), 77857791. DOI: https://doi.org/10.33258/birci. v4i4.2697.

10. Tjiptono, Fandy. (2008). Strategi Pemasaran. Edisi 2. Yogyakarta: Andi Offset.

11. Tjiptono, Fandy. (2010). Strategi Pemasaran. Edisi 3. Yogyakarta: Andi Offset.

12. Tjiptono, Fandy. (2015). Strategi Pemasaran. Edisi 4. Yogyakarta: Andi Offset.

13. Tobing, Murniati, Afifuddin, Sya'ad, Rahmanta, Huber, Sandra Rouli,
Pandiangan, Saut Maruli Tua, \& Muda, Iskandar. (2018). An Analysis on the Factors Which Influence the Earnings of Micro and Small Business: Case at Blacksmith Metal Industry. Academic Journal of Economic Studies, 5(1), 17-23. https://www.ceeol.com/search/articledetail ?id=754945.

How to cite this article: Rosinta Romauli Situmeang, Eci Maria Romanasari Situmorang, Ivan Setiawan et.al. Effect of price, promotion, and product quality on Telkomsel customer loyalty to management study program students at Universitas Prima Indonesia. International Journal of Research and Review. 2021; 8(12): 167-171. DOI: https://doi.org/10.52403/ijrr. 20211222 